\title{
Effect of Domestic and Global Environmental Events on Environmental Concern and Environmental Responsibility among University Students
}

\author{
Piyapong Janmaimool $* \mathbb{D}$ and Surapong Chudech \\ Department of Social Sciences and Humanities, School of Liberal Arts, King Mongkut's University of Technology \\ Thonburi, 126 Prachauthit Road, Thungkru District, Bangkok 10140, Thailand; Surapong.chu@kmutt.ac.th \\ * Correspondence: piyapong.jan@kmutt.ac.th
}

Received: 3 January 2020; Accepted: 19 February 2020; Published: 21 February 2020

\begin{abstract}
Recently, both global and domestic environmental events have been occurring more frequently, bringing catastrophic consequences to humans and the environment. These adverse events have caused widespread concern among the general public. In positive terms, these devastating events could potentially enhance people's environmental concern, which, in turn, could instill a greater sense of environmental responsibility. This study aims to examine how global and domestic environmental concerns mediate the effect of environmental knowledge and attitudes on environmental responsibility. Students of King Mongkut's University of Technology Thonburi in Bangkok, Thailand, were selected as the participants. A simple random technique was applied for selecting the participants. Questionnaire surveys with 863 students were carried out during September-October 2019. A path analysis was performed to test relationships among environmental knowledge, environmental attitudes, global and domestic environmental concerns, and environmental responsibility. The results demonstrated that domestic environmental concerns, taken alone, contributed less to the students' sense of environmental responsibility. Domestic environmental concerns had a stronger effect on environmental responsibility when taken together with global environmental concerns. In addition, both domestic and global environmental concerns could help transform environmental knowledge and attitudes into environmental responsibility. Only environmental attitudes had no direct effect on responsibility. These results show that domestic and global catastrophic environmental events could raise students' levels of concern for the environment, and, ultimately, enhance their sense of moral responsibility to protect the environment.
\end{abstract}

Keywords: global environmental concerns; domestic environmental concerns; environmental attitudes; environmental responsibility

\section{Introduction}

Recently, the general public has experienced several catastrophic environmental events, including both domestic and global events. In Thailand, Bangkok's particulate matter $\left(\mathrm{PM}_{2.5}\right)$ concentration crisis from November 2018 until January 2019 and in September 2019 caused health concerns and health impacts, not only among vulnerable groups (e.g., elderly people and the poor), but also among the general public. $\mathrm{PM}_{2.5}$ refers to particulate matter with diameters of 2.5 micrometers $(\mu \mathrm{m})$ or less. A high concentration of $\mathrm{PM}_{2.5}$ in a particular area potentially causes toxic health effects. The Pollution Control Department of Thailand reported that the concentration of $\mathrm{PM}_{2.5}$ in many areas was higher than the air quality index (AQI) which indicates an acceptable range of air quality [1]. In Thailand, the annual standard for $\mathrm{PM}_{2.5}$ concentrations is set at $25 \mu \mathrm{g} / \mathrm{m}^{3}$ and the daily standard is set at $50 \mu \mathrm{g} / \mathrm{m}^{3}$ [1]. Public concern about $\mathrm{PM}_{2.5}$ concentrations led to the urgent need for government action to manage 
the problem. Besides $\mathrm{PM}_{2.5}$ concentration in Bangkok, several parts of Thailand also faced many environmental catastrophic events, including shorter winter periods, rising temperatures in Bangkok during summer, and heavy floods in northeastern Thailand (see Table 1). On a global scale, many other catastrophic events have recently occurred in several parts of the world. Those events include fires in the Amazon rainforest, death of aquatic animals due to waste in the oceans, changes in global average temperature, decline of polar bears at the North Pole, and sea level rise (see Table 1). These global environmental events reflect a global environmental crisis that is having serious impacts on both ecosystems and human well-being. All of these problems have been highlighted in both national and international public media.

Table 1. Catastrophic Environmental Events Occurring in Thailand and Other Countries.

\begin{tabular}{|c|c|c|}
\hline & $\begin{array}{c}\text { Catastrophic } \\
\text { Environmental Events }\end{array}$ & Situations \\
\hline \multirow{4}{*}{ Domestic } & $\begin{array}{c}\mathrm{PM}_{2.5} \text { concentration in } \\
\text { Bangkok }\end{array}$ & $\begin{array}{l}\text { During November 2018-January } 2019 \text { and in September 2019, Bangkok's } \\
\text { atmosphere was full of particulate matter }\left(\mathrm{PM}_{2.5}\right) \text {, with concentrations higher } \\
\text { than the air quality index in many areas. For instance, on December 21, 2018, the } \\
\text { Pollution Control Department of Thailand reported that the concentration of } \\
\text { PM }_{2.5} \text { along Dingdang Road was } 100 \mu \mathrm{g} / \mathrm{m}^{3} \text {, which was two times higher than } \\
\text { the air quality index }\left(50 \mu \mathrm{g} / \mathrm{m}^{3}\right)[1] \text {. }\end{array}$ \\
\hline & $\begin{array}{c}\text { Shorter winter period in } \\
\text { Thailand }\end{array}$ & $\begin{array}{l}\text { Thailand has been facing shorter winter periods. According to Limsakul et al. [2], } \\
\text { it is expected that the northern and northeastern parts of Thailand would } \\
\text { experience the reduction of cold period after mid-century from } 2-2.5 \text { months to } \\
1-2.5 \text { months. This means the number of cold days with temperature }<16^{\circ} \mathrm{C} \\
\text { would be reduced. }\end{array}$ \\
\hline & $\begin{array}{l}\text { Rising temperatures in } \\
\text { Bangkok during summer }\end{array}$ & $\begin{array}{l}\text { The Thailand Meteorological Department [3] reported that from } 1995-2009 \text {, the } \\
\text { average annual temperatures had increased by about } 0.95{ }^{\circ} \mathrm{C} \text {; whereas, the } \\
\text { average world temperature increase was } 0.69^{\circ} \mathrm{C} \text { [4]. Limsakul et al. [2] also } \\
\text { found that the number of warm days which were higher than } 35^{\circ} \mathrm{C} \text { daily mean } \\
\text { temperature/year was predicted to rise, especially in the Chao Phraya River basin } \\
\text { as well as the central plain and the lower northern regions. As a result of the } \\
\text { increase in the number of warm days, an extension of the summer period by } 2-3 \\
\text { months on average would happen. Consequently, by the end of the century, the } \\
\text { northeastern, central and southern parts of Thailand are estimated to have hot } \\
\text { periods extended to } 5-6 \text { months. }\end{array}$ \\
\hline & $\begin{array}{l}\text { Heavy floods in } \\
\text { northeastern Thailand }\end{array}$ & $\begin{array}{l}\text { Limsakul and Singhruck [5] found that central and eastern Thailand would face } \\
\text { decreases in total rainfall, whereas the northeast, the Gulf regions and Bangkok, } \\
\text { would experience increasing rainfall. The Thailand Meteorological Department } \\
\text { [3] also reported that Thailand would face more intense tropical storms during } \\
\text { the alteration of seasons from rainy to winter and winter to summer. On } 29 \\
\text { August 2019, Tropical Storm Podul passed through Thailand, followed by } \\
\text { Tropical Depression Kajiki on } 3 \text { September 2019, which enhanced the southwest } \\
\text { monsoon. Heavy floods occurred in many provinces across Thailand, } \\
\text { particularly in the northeastern regions, including the Ubon Ratchathani, } \\
\text { Yasothon, Roi Et and Sri Saket provinces. More than 20,000 people from Ubon } \\
\text { Ratchathani and Sri Saket evacuated to } 49 \text { evacuation centers [6]. }\end{array}$ \\
\hline
\end{tabular}


Table 1. Cont.

\begin{tabular}{|c|c|c|}
\hline & $\begin{array}{c}\text { Catastrophic } \\
\text { Environmental Events }\end{array}$ & Situations \\
\hline \multirow{5}{*}{ Global } & $\begin{array}{l}\text { Fires in the Amazon } \\
\text { rainforest }\end{array}$ & $\begin{array}{l}\text { The Amazon basin contains almost three million species of plants and animals } \\
\text { [7], and } 350 \text { groups of about one million indigenous people [8]. The Amazon } \\
\text { rainforests provide ecological services for the world's population by absorbing } \\
\text { millions of tons of carbon every year [8]. When large numbers of trees are cut or } \\
\text { burned, the carbon stored in those trees is released into the atmosphere. From } 1 \\
\text { January until } 29 \text { August } 2019 \text {, the INPE reported that Brazil faced more than } \\
80,000 \text { fires [9]. It was estimated that more than } 906,000 \text { hectares ( } 2.24 \times 106 \text { acres; } \\
9060 \mathrm{~km}^{2} ; 3500 \text { sq mi) of Amazon forest have been lost due to fires in } 2019 \text {. These } \\
\text { fires raised environmental concerns, not only in Brazil, but around the world due } \\
\text { to the excess carbon dioxide and carbon monoxide in the fires' emissions. }\end{array}$ \\
\hline & $\begin{array}{c}\text { Death of aquatic animals } \\
\text { due to waste in the } \\
\text { oceans }\end{array}$ & $\begin{array}{l}\text { According to the report "Marine Debris: Understanding, Preventing and } \\
\text { Mitigating the Significant Adverse Impacts on Marine and Coastal Biodiversity" } \\
\text { [10], approximately } 663 \text { to } 817 \text { species worldwide have been affected by marine } \\
\text { debris since 2012, and about } 80 \% \text { of marine litter is plastic. Many studies have } \\
\text { found that micro- and nano-plastics in oceans have caused ecological impacts on } \\
\text { flora and fauna, such as dolphins, whales, sea turtles, sea lions and seals [11]. } \\
\text { The effects of plastic pollution on marine life have been highlighted in the public } \\
\text { media, both domestically and internationally. This media attention can raise } \\
\text { people's level of concern about this problem. }\end{array}$ \\
\hline & $\begin{array}{l}\text { Changes in global } \\
\text { average temperature }\end{array}$ & $\begin{array}{l}\text { The NOAA } 2018 \text { Global Climate Summary reported that there was an increase in } \\
\text { the combination of land and ocean temperature at an average rate of } 0.07 \\
{ }^{\circ} \mathrm{C} / \text { decade since } 1880 \text {. Since } 1981 \text {, the average rate of increase has been } 0.17^{\circ} \mathrm{C} \text {, } \\
\text { which is more than double the prior rate. These projections also show that global } \\
\text { surface temperatures will be higher than } 0.5^{\circ} \mathrm{C} \text { warmer than the } 1986-2005 \\
\text { average by } 2020 \text { [12]. Many regions in the world, including New Zealand, the } \\
\text { Middle East, Europe and the Mediterranean Sea, experienced record warm years. } \\
\text { Some regions, such as Canada and the north-central United States were reported } \\
\text { cooler than average [12]. }\end{array}$ \\
\hline & $\begin{array}{l}\text { Decline of polar bears at } \\
\text { the North Pole }\end{array}$ & $\begin{array}{l}\text { Naturally, the polar bear relies on sea ice for the purposes of feeding, breeding } \\
\text { and moving. They mostly live in Arctic areas where the land is covered by ice for } \\
\text { almost the whole year. Their preferred habitat is the continental shelf where the } \\
\text { polar bear can easily search for prey, including ringed seals and bearded seals } \\
\text { [13]. The reduction of sea ice during the summer potentially minimized foraging } \\
\text { success and caused nutritional stress [14]. Hunter et al. [15] found that global } \\
\text { warming caused significant reductions of sea ice in Arctic areas; thus, they } \\
\text { predicted that the polar bear population would rapidly decrease by the end of } \\
\text { the } 21 \text { st century. According to Bromaghin et al. [16], northeastern Alaska and the } \\
\text { Northwest Territories faced a } 40 \% \text { loss of polar bear populations (from } 1500 \text { to } \\
900 \text { bears) from } 2001-2010 \text {. }\end{array}$ \\
\hline & Sea level rise & $\begin{array}{l}\text { Sea level rise is one of the adverse consequences of climate change [17]. There are } \\
\text { several reasons that a warming climate could potentially cause rising sea levels, } \\
\text { including the melting of marine ice-sheets and thermal expansion of sea water. } \\
\text { Many previous studies have analyzed sea level rise as a consequence of climate } \\
\text { warming. It has been estimated that sea levels rose globally by about } 15-20 \mathrm{~cm} \text { in } \\
\text { the past century [18], and sea levels will continue to increase in the } 21 \mathrm{st} \\
\text { century [19]. }\end{array}$ \\
\hline
\end{tabular}

Although these catastrophic environmental events cause diverse negative impacts on human well-being and natural ecosystems, both domestically and internationally, these events could help raise the level of environmental concern among people, and ultimately, lead to a greater individual sense of environmental responsibility. Many studies have explored the essential role of environmental knowledge and environmental attitudes in promoting an individual sense of environmental responsibility and pro-environmental behaviors [20,21]. Some previous studies have also identified the roles of environmental concerns in predicting people's environmentally-related behaviors [22-24], as well as the link between attitudes toward the environment and environmental concerns [25]. However, the influence of global and domestic environmental concerns, generated from the recent occurrence of catastrophic environmental events, on the relationship between knowledge/attitudes and a sense of environmental responsibility has never been investigated. Understanding the associations among 
environmental knowledge, attitudes, domestic and global environmental concerns, and a sense of environmental responsibility could have implications for the development of better communication regarding the consequences of current catastrophic environmental events. Such effective communication could help promote citizen participation in pro-environmental behaviors.

This study aims to investigate university students' concerns about global and domestic catastrophic environmental events and to examine how global and domestic environmental concerns mediate the effect of environmental knowledge and attitudes on university students' sense of environmental responsibility. The participants of this study were university students of King Mongkut's University of Technology Thonburi in Bangkok, Thailand. The results of this study may provide strategies for communicating with or educating university students about the consequences of global and domestic catastrophic environmental events and relevant environmental issues in order to enhance their sense of environmental responsibility.

\section{Literature Review}

\subsection{Environmental Responsibility}

In this study, environmental responsibility (ER) refers to a sense of personal obligation towards the environment or feelings of responsibility to take action to avoid undesirable impacts on the environment. Han et al. [26] conceptualized ER as feelings of personal responsibility to perform a particular behavior that is friendly to society and the environment. Regarding the value-belief-norm theory (VBN), environmental responsibility is an important variable which potentially contributes to personal norms, and personal norms have a significant effect on an individual's decision to engage in pro-environmental behaviors (PEBs) [27]. ER is therefore considered important to promote PEBs. Many scholars also contend that ER significantly contributes to an individual's readiness to engage in PEBs [28-30]. Clark et al. [25], for instance, stated that ER enables individuals to act for environmental protection. Similarly, Zhu et al. [31] demonstrated that different levels of perceived responsibility contribute to an individual's conservation intentions. ER potentially persuades both a person and organizations to be responsible for causing various environmental problems due to their behaviors and to alter their daily practices to minimize negative consequences [32]. ER is greatly related to personal norms, which could be generated from both feelings of moral obligations towards societies and/or nature and personal feelings of obligation due to social pressures [33,34]. This study emphasizes the role of personal feelings of moral obligations towards societies and/or nature in creating ER. To create these type of feelings, roles of environmental knowledge, environmental attitudes, and environmental concerns are assumed to be influential because they enable individuals to understand the links among environmental problems, root causes of the problems, and seriousness of consequences, and to recognize their important roles in solving the problems. Thus, variables related to environmental knowledge, environmental attitudes, and global and domestic environmental concerns were selected to investigate their influence on ER.

\subsection{Environmental Attitude}

Environmental attitude (EA) has been defined by scholars in different ways. Schultz et al. [35] conceptualized EA as an individual's beliefs, affects and behavioral intentions related to environmentallyrelated issues. EA can be measured based on people's beliefs about the natural environment, and beliefs could be positive or negative [36]. Lee and Choi [37] conceptualized EA into three aspects, including (1) environmental beliefs that refer to people's notions about the relationship between humanity and the natural environment, (2) environmental values, which refer to one's beliefs about significance of natural environment, and (3) environmental sensitivity, which refers to one's recognition of the seriousness of environmental problems and notions about the influence of human activities on environmentally-related problems. Kim [38] concluded that environmental attitude (EA) could be defined in three different ways such as attitudes toward environmental issues, attitudes toward 
environmental behaviors, and environmental worldviews. The study of Schultz et al. [35] indicated that individuals' environmental worldviews could influence attitudes toward environmental issues and environmental behaviors. For this study, environmental attitude refers to individuals' general beliefs about the relationships between human and nature. This is called environmental worldview or general environmental attitude [39].

Many studies have shown that positive environmental attitudes are significantly correlated with PEBs [40,41], and PEBs are significantly contributed by sense of environmental responsibility [25,31]. However, some studies also found a weak correlation between positive environmental attitudes and green behaviors [42,43], and Vermeir and Verbeke [44] demonstrated that the single variable of environmental attitudes was too weak to predict PEBs. According to the VBN theory, people who have positive environmental attitudes will be able to recognize the undesirable consequences of certain behaviors for the environment, and this recognition can finally create a sense of personal obligation to act environmentally. To measure people's general environmental attitudes or environmental worldviews, the new environmental paradigm (NEP) scale, as proposed by Dunlap and Van Liere [39], has been widely used [45,46]. For instance, Arcury [47] measured individuals' attitudes toward the environment by using the NEP scale and found a significant relationship between environmental knowledge and attitudes. The new NEP scale consists of 15 items and has five sub-scales. Those scales and items aim to measure people's perceptions of issues related to the interconnection between humans and the environment, such as limits to growth, anti-anthropocentrism, the fragility of nature's balance, the rejection of exemptionalism and the possibility of an eco-crisis [48]. The reliability of the NEP scale has been tested in many previous studies and the result showed that NEP could be a valid tool to evaluate people's perceptions of environmental values [42,49]. Halkos and Matsiori [50] also applied the NEP scale to measure environmental attitudes.

\subsection{Environmental Knowledge}

Environmental knowledge (EK) means one's ability to identify the symbols, concepts and behavior patterns pertaining to environmental protection and ecological conservation according to received environmental information [51]. Chan [52] defined EK as one's understanding of knowledge of the nature, environments, and relevant issues, such as current environmental situations, the causes of environmental problems and possible impacts. Previous studies have shown that EK could enhance environmental concerns and awareness for environmental problems [21,53]. For instance, Lee [54], Mostafa [55] and Oguz et al. [56] indicated that by having greater knowledge of environmental problems or environmental issues, people tend to behave more environmentally. Similarly, Flamm [57] showed that households reporting their engagement in purchasing energy-efficient cars had relatively higher levels of EK. However, some studies found that fostering singular knowledge tended to have a low impact on people's engagement in environmental behaviors [58,59]. EK may contribute to individuals' positive attitudes towards pro-environmental behaviors, which may ultimately encourage participation in environmentally-friendly behaviors. Mostafa [60] also showed that EK has a positive impact on consumers' attitudes towards green products. Similarly, Sang [61] found a significant effect of EK on attitudes towards green purchasing behaviors. Considering measurement of EK, EK can be divided into 2 types based on measurement methods. The first type is subjective knowledge which is measured by exploring an individual's perception of understanding about the nature and environment, and the second one is objective knowledge which is measured by examining an individual's actual knowledge acquisition [62]. For this study, environmental knowledge will be measured by employing self-reporting techniques, so it is called perceived EK (subjective knowledge) [62]. Therefore, environmental knowledge in this study refers to perceived environmental knowledge (PEK).

\subsection{Environmental Concern}

Environmental concern (EC) was conceptualized as the degree to which individuals are concerned about environmental problems and dangers to the earth's ecosystems and to natural sustainability $[63,64]$. 
Similarly, Singh and Bansal [65] viewed EC as people's consciousness toward environmental and ecological problems and their perceptions of the necessity of environmental problem-solving actions. In other words, EC is related to people's awareness of environmental problems, which can be indicated in several ways, including attitude, recognition and personal response towards environmental issues [66]. Many scholars also used the term "environmental concern" for explaining individuals' attitudes toward the environment and environmental behaviors, and these attitudes were presented as positive or negative attitudes. For this study, environmental concern specifically refers to the degree to which people are concerned about environmental problems which are divided into global and domestic environmental problems. Abdul-Muhmin [67] stated that the occurrence of environmental events that posed a threat to nature and interrupted the balance between humans and nature, on both the regional and international levels, appeared to positively affect the levels of ecological and environmental concern. Wu et al. [68] demonstrated that EC played an important role in predicting behavioral intentions to accept autonomous electric vehicles.

Currently, there are many global environmental issues that may contribute to individuals' levels of concern, including climate change, loss of biodiversity and natural disasters. Climate change is one of the hot issues that concern many scholars and the general public as it could potentially change global ecological and social systems [69]. The impacts of climate change can cause catastrophic environmental events, both on the regional and global levels, such as tropical storms, global warming, sea level rise (SLR) and coastal erosion. In addition to global environmental issues, local and regional environmental issues could also concern many people as they could obviously generate negative effects for people living in the problem areas. Local environmental issues are related to domestic environmental events, such as air pollution, wastewater pollution and solid waste problems. Both global and domestic environmental events could positively contribute to people's environmental concerns, which could ultimately lead to a sense of environmental responsibility to protect the environment. However, the potential influence on individuals' environmental responsibility has never been empirically tested.

\section{Conceptual Idea of the Study}

This study aims to reveal the roles of global and domestic environmental concerns in mediating the effect of environmental knowledge and environmental attitudes on people's sense of environmental responsibility. The proposed conceptual framework for this study can be seen in Figure 1.

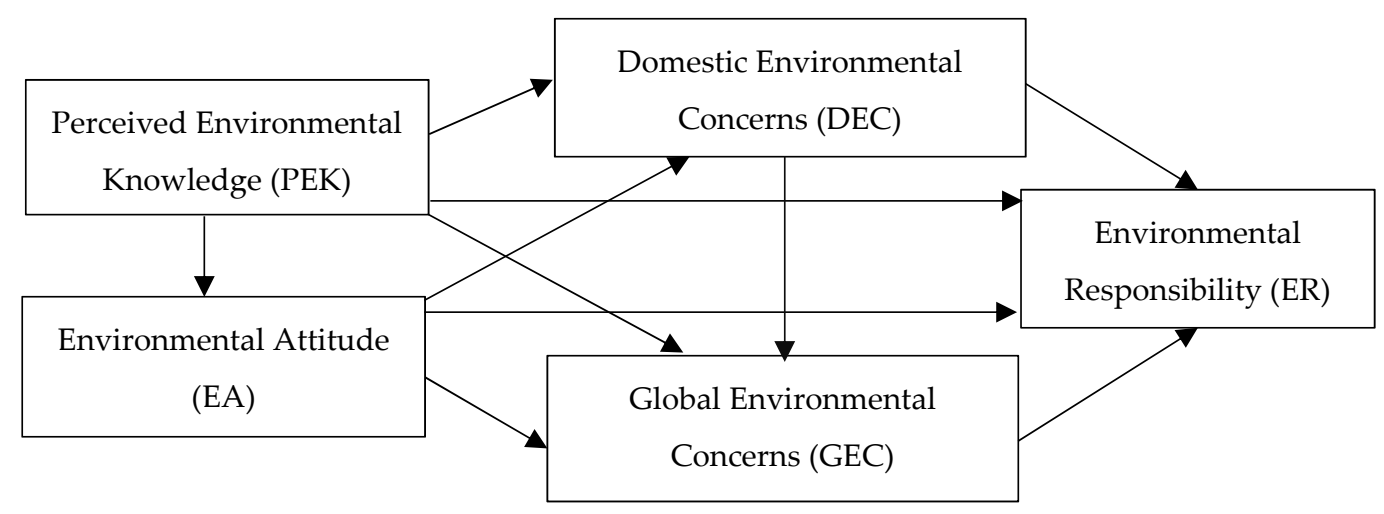

Figure 1. Conceptual Idea of the Study.

Overall, perceived environmental knowledge (PEK) and environmental attitude (EA) are assumed to have a direct effect on environmental responsibility (ER) and to have indirect effects on ER through both domestic environmental concerns (DEC) and global environmental concerns (GEC). By having a certain level of PEK and a positive EA, people can construct appropriate levels of concern about environmental issues related to global and domestic environmental events, which, in turn, affect ER. As stated in the VBN theory [27], having a positive EA could contribute to a moral responsibility to protect 
the environment, which, in turn, could affect individuals' decision to engage in pro-environmental behaviors. It can be also assumed that people with a positive EA may construct appropriate levels of EC, including both DEC and GEC. Widegren [70] showed that people acquired their EA over time and that a positive EA could help increase EC. Moreover, this study also assumed that DEC might also affect GEC, particularly when people acquire a certain level of environmental knowledge and attitudes. Well understanding of ecosystem functions and characteristics of the nature could enable individuals to relate local environmental conditions to global environmental conditions. As stated by Maharjan and Joshi [71], people's understanding of local environmental phenomena relatively contributes to their understanding of global climate situations. Basically, individuals could have less concern about global environmental issues due to a lack of sense of urgency about being impacted by global environmental events. Nash et al. [72] found that people's perception on global climate change could be limited due to being beyond their perceptual capacity; whereas, local environmental phenomena could be better perceived due to immediate catastrophic effects. However, it is possible that individuals' concern about domestic environmental events could finally influence global environmental concerns when they have sufficient environmental knowledge to relate those two environmental issues and have positive environmental attitudes to promote the concerns.

In addition, PEK can also positively and directly contribute to EA. Namely, individuals with appropriate environmental knowledge could have a positive attitude towards the environment. For instance, Bradley et al. [73] found a significant link between the PEK and EA of students. EA can also positively and directly affect EC. As stated by Ünal, Steg and Gorsira [53], environmental knowledge can enhance individuals' concerns and awareness of environmental problems. Wurzinger and Johansson [74] also found that tourists with more environmental knowledge reported a relatively greater EC for the environmental issues related to tourism destinations. Moreover, it also can be assumed that PEK could have a significant effect on EC through EA. Hunter and Rinner [75] reported that environmental knowledge could contribute to EC with the support of EA, regarding people's participation in species preservation behaviors. Finally, when having a certain level of EC, people are expected to construct a sense of ER. As found by Wu et al. [68], Lin and Huang [76], and Prakash and Pathak [77], EC expressed as individuals' environmental awareness can strengthen their sense of ER and guide them to act in an environmentally-friendly manner.

In this study, it was assumed that both DEC and GEC could have different degrees of effect on ER and could have different levels of power in mediating the effect of PEK and EA on ER. Thus, the results will have implications for strategic communication of catastrophic environmental consequences with the purpose of enhancing an individual sense of ER.

\section{Research Methods}

\subsection{Participants and Ethical Issues}

This study had undergraduate students (18-23 years old) as participants. They enrolled in King Mongkut's University of Technology Thonburi (KMUTT), Bangkok, Thailand. In the 2019 academic year, there were 11,858 students. This study employed a simple random sampling method to select participants. The size of the sampling population was calculated based on the Yamane formula [78] with a $96.0 \%$ confidence level. The results revealed that 594 participants were at least required. However, in the data collection, questionnaire sheets with consent forms were distributed to 1000 students, and 863 students decided to engage in the survey ( $86.3 \%$ response rate). This research project was also approved by the Research Ethics Committee of the School of Liberal Arts, KMUTT.

\subsection{Instruments}

A questionnaire was developed and used for data collection. Before using, it was inspected for its validity by measuring its face validity, and the questionnaire was tested with 30 undergraduate students to confirm the reliability of the questionnaire items. The internal consistency of the scales, 
which were developed for measuring levels of PEK, EA, DEC, GEC and ER, were tested by calculating Cronbach's alpha. The results of calculation came out that the values of Cronbach's alpha for each variable were greater than 0.70 , thus the items developed for measuring all variables in this study were reliable [79]. All questionnaire items are shown in Table 2.

In measuring environmental knowledge, this study measured participants' perceived environmental knowledge (subjective knowledge) by employing self-reporting techniques. The five-item PEK scale was developed based on the application of the PEK scale established by Zhu [80]. Zhu's PEK scale [80] was also used by Pan et al. [81]. For this study, a questionnaire item related to local environmental knowledge was also added.

For measurement of environmental attitude (EA), this study measured EA based on direct self-reporting techniques by applying the new environmental paradigm (NEP) scale [48]. Many previous studies also relied on self-reporting techniques [82] and the NEP scale to measure EA [83]. The NEP scale aims to measure people's perception of, or belief about, the relationship between humans and the environment [48]. The revised NEP scale contains 15 items. For this study, only six items were selected based on the consideration of students' capabilities to understand meanings and contexts related to each question. This change ensured the reliability of the collected data.

Table 2. Variables, Explanations and Questions for Data Collection.

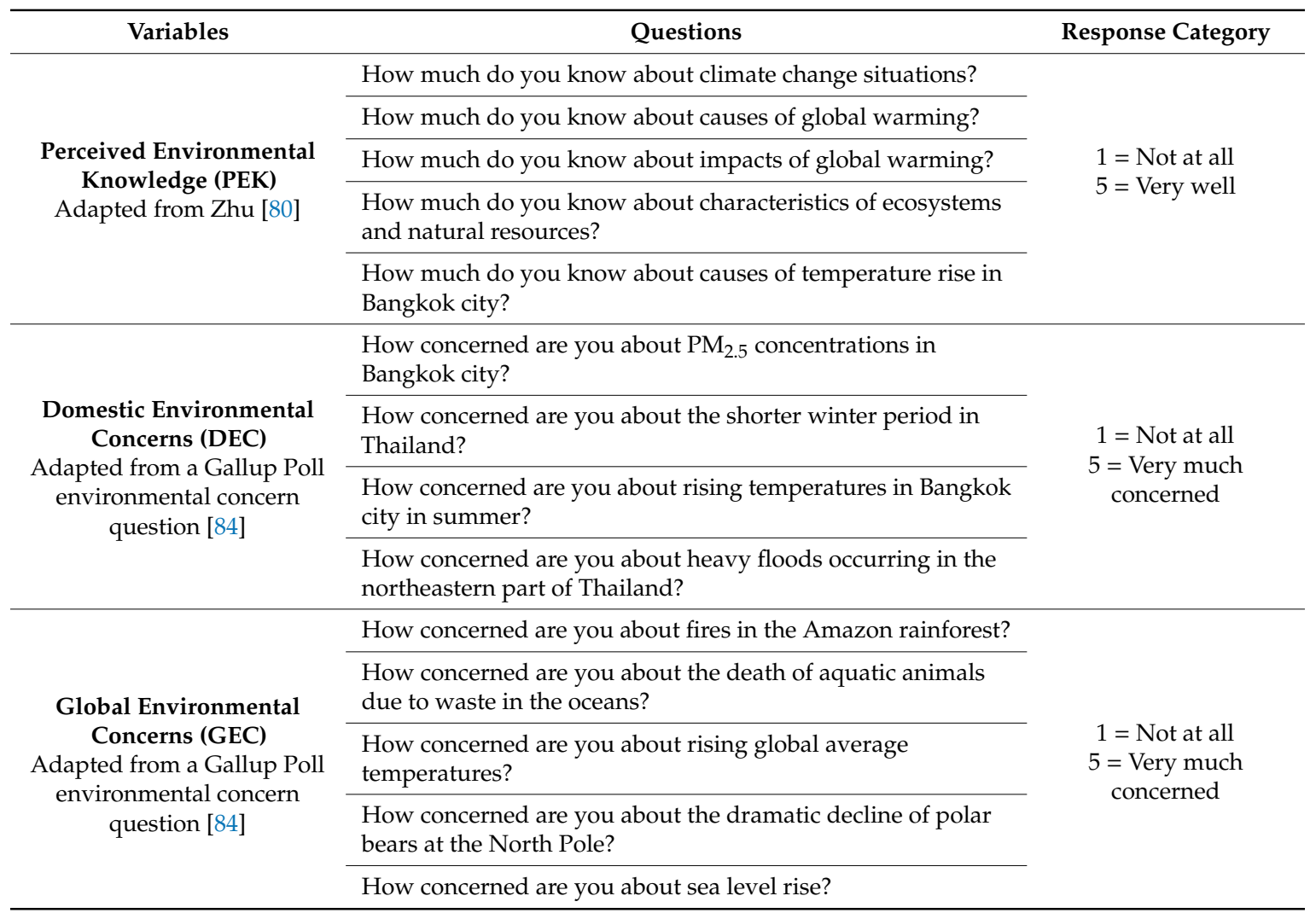


Table 2. Cont.

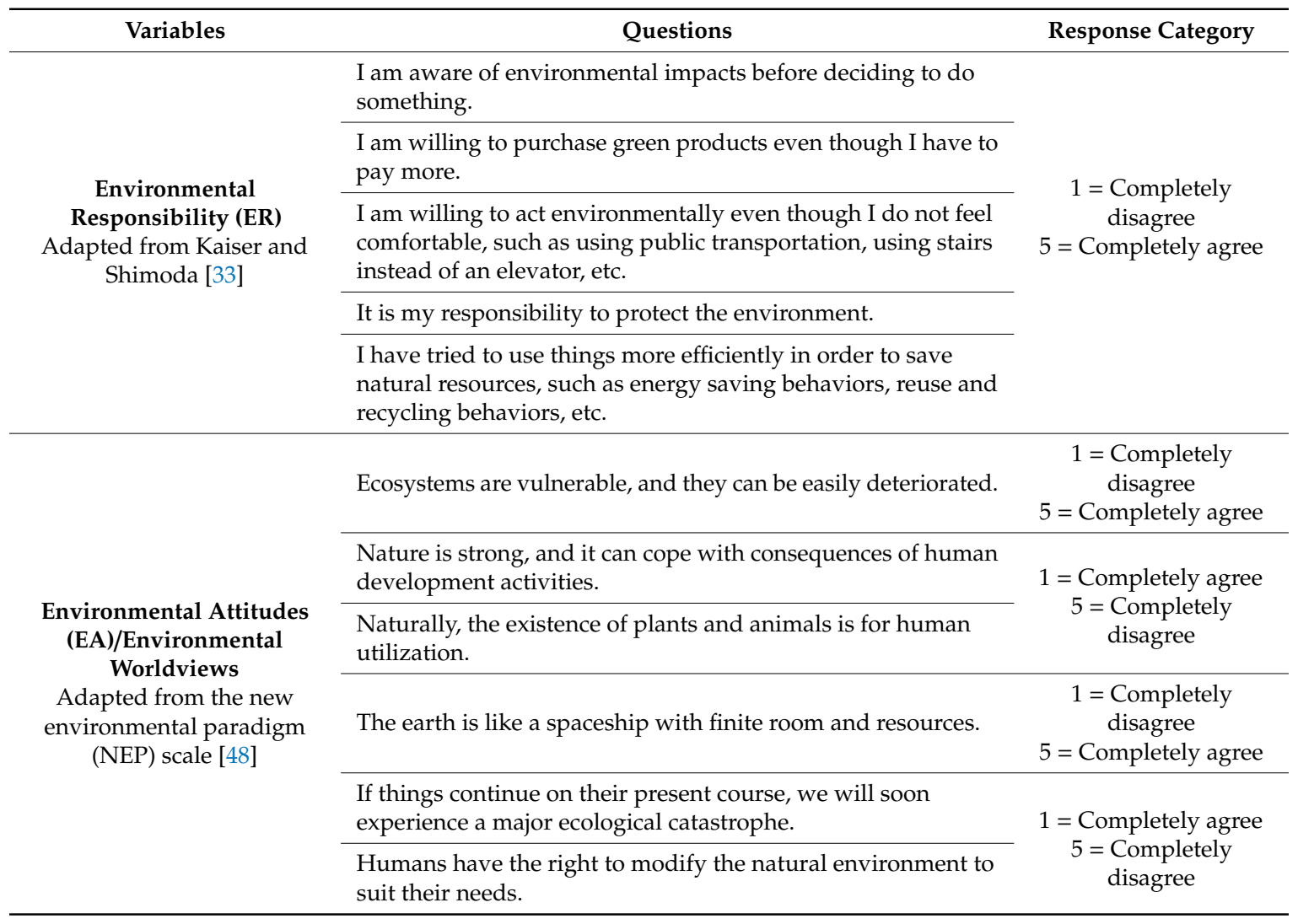

Regarding environmental concern (EC), EC was divided into domestic environmental concern (DEC) and global environmental concern (GEC). DEC refers to individuals' concerns about catastrophic environmental problems occurring in Thailand during the past decade. These include PM2.5 concentrations in Bangkok during 2018-2019, shorter winter periods, rising temperatures in Bangkok during the summer season and heavy floods occurring in the northeastern part of Thailand during August and September 2019. GEC refers to individuals' concerns about environmental problems occurring in other countries or another part of the world. These problems reflect adverse impacts on the world's macro environmental and ecological systems. These problems include fires in the Amazon rainforest, the death of aquatic animals due to waste in the oceans, rising global average temperatures, a dramatic decline in the polar bear population at the North Pole and sea level rise. For the measurement of DEC and GEC, a five-point Likert scale, ranging from 1 (not at all) to 5 (very much concerned), was developed based on the application of a Gallup Poll environmental concern question [84]. Participants were asked to indicate how concerned they were about relevant environmental events.

In measuring environmental responsibility (ER), this study measured participants' feelings of moral responsibility towards the environment based on a combination of diverse dimensions including feelings of responsibility to protect the environment, willingness to act environmentally, awareness of negative impacts caused by behaviors, and environmentally-related behaviors. These aspects can reflect individuals' feeling of moral responsibility [33,85]. A five-point Likert scale with responses ranging from 1 (completely disagree) to 5 (completely agree) was developed based on the application of questions developed by Kaiser and Shimoda [33].

\subsection{Data Collection and Analysis}

Data collection by questionnaire surveys was carried out during September and October 2019 at King Mongkut's University of Technology Thonburi in Bangkok, Thailand. All collected data were inspected before being used for statistical analysis. For the data analysis, a path analysis was carried out 
to test the conceptual model in Figure 1. Undergraduate students' ER was defined as an endogenous variable that might be influenced by GEC and DEC, which were defined as exogenous variables. Moreover, both GEC and DEC were also defined as endogenous variables that might be influenced by two exogenous variables, including EA and PEK. The variable of EA was also an endogenous variable that might be affected by PEK. The developed path model is illustrated in Figure 1. The evaluation of model fit was performed by calculating these indexes: $\chi 2$ test, root mean square error of approximation (RMSEA), comparative fit index (CFI), goodness-of-fit indexes (GFIs), chi square/degree of freedom ratio (CMIN/DF) and incremental fit index (IFI). The evaluation was carried out by using statistical software Analysis of Moment Structure (AMOS) version 21.

\section{Research Methods}

\subsection{Characteristics of Participants and Variable Scores}

Table 3 presents the characteristics of the participants and the participants' reported scores of variables, including PEK, DEC, GEC, ER and EA. The proportion of female participants was slightly higher than male participants, with $52 \%$ and $48 \%$, respectively. There were 373 participants studying in their 4 th year, which accounted for the highest proportion at $43.20 \%$. There were 130 participants, or $15.10 \%$, studying in their 1st year, which was the smallest group. Participants in their 2nd and 3rd years numbered 190 (22\%) and 170 (19.70\%), respectively. Considering participants' fields of study, the results showed that $41.6 \%$, or 359 students, were studying engineering, and $29.5 \%$, or 255 participants, were studying science and technology. The proportion of participants in information technology was the smallest, with only $4.6 \%$. The average GPA reported by all participants was $\mathrm{M}=2.70, \mathrm{SD}=0.494$.

Table 3. Characteristics of the survey participants.

\begin{tabular}{|c|c|c|c|}
\hline \multicolumn{2}{|c|}{ Items } & $\mathbf{n}$ & Percent \\
\hline \multirow{2}{*}{ Gender } & Male & 414 & $48 \%$ \\
\hline & Female & 449 & $52 \%$ \\
\hline \multirow{4}{*}{ School Year } & First Year & 130 & $15.10 \%$ \\
\hline & Second Year & 190 & $22 \%$ \\
\hline & Third Year & 170 & $19.70 \%$ \\
\hline & Fourth Year & 373 & $43.20 \%$ \\
\hline \multirow{5}{*}{ Fields of Study } & Engineering & 359 & 41.6 \\
\hline & Science and Technology & 255 & 29.5 \\
\hline & Information Technology & 40 & 4.6 \\
\hline & Industrial Education & 137 & 15.9 \\
\hline & Arts and Media & 72 & 8.3 \\
\hline GPA & & \pm 0.4 & \\
\hline
\end{tabular}

Table 4 shows the average scores of PEK, DEC, GEC, ER and EA reported by participants. Compared with other variables, the participants reported the highest average scores for GEC (M = $4.17, \mathrm{SD}=0.75)$ and DEC $(\mathrm{M}=4.01, \mathrm{SD}=0.69)$. EA had the lowest score $(\mathrm{M}=3.55, \mathrm{SD}=0.56)$. ER had an average score of 3.82 with a standard deviation of 0.53 , and PEK had an average score of 3.69 with a standard deviation of 0.56. Regarding GEC, it was found that participants reported the highest concern about the death of aquatic animals due to waste in the oceans $(\mathrm{M}=4.29, \mathrm{SD}=0.75)$, whereas they reported the lowest concern about the dramatic decline of polar bears at the North Pole $(\mathrm{M}=4.05$, $\mathrm{SD}=0.62$ ). For DEC, participants reported the highest concern about rising temperatures in Bangkok in the summer $(\mathrm{M}=4.15, \mathrm{SD}=0.70)$ and heavy floods occurring in the northeastern part of Thailand 
$(\mathrm{M}=4.15, \mathrm{SD}=0.72)$. Participants reported the lowest concern about the shorter winter period in Thailand $(\mathrm{M}=3.74, \mathrm{SD}=0.65)$.

Table 4. Levels of environmental knowledge, local environmental concerns, global environmental concerns, environmental responsibility, and environmental attitude.

\begin{tabular}{|c|c|c|c|}
\hline Variables & Mean & SD & Cronbach's $\alpha$ \\
\hline Perceived Environmental Knowledge (PEK) & 3.69 & 0.56 & \multirow{6}{*}{0.798} \\
\hline How much do you know about climate change situations? & 3.69 & 0.45 & \\
\hline How much do you know about causes of global warming? & 3.97 & 0.50 & \\
\hline How much do you know about impacts of global warming? & 4.01 & 0.65 & \\
\hline $\begin{array}{l}\text { How much do you know about characteristics of ecosystems and } \\
\text { natural resources? }\end{array}$ & 3.26 & 0.50 & \\
\hline How much do you know about causes of temperature rising in Bangkok city? & 3.53 & 0.70 & \\
\hline Domestic Environmental Concerns (DEC) & 4.01 & 0.69 & \multirow{5}{*}{0.731} \\
\hline How concerned are you about $\mathrm{PM}_{2.5}$ concentrations in Bangkok city? & 4.01 & 0.67 & \\
\hline How concerned are you about the shorter winter period in Thailand? & 3.74 & 0.65 & \\
\hline How concerned are you about rising temperatures in Bangkok city in summer? & 4.15 & 0.70 & \\
\hline $\begin{array}{l}\text { How concerned are you about heavy floods occurring in the northeastern part } \\
\text { of Thailand? }\end{array}$ & 4.15 & 0.72 & \\
\hline Global Environmental Concerns (GEC) & 4.17 & 0.75 & \multirow{6}{*}{0.871} \\
\hline How concerned are you about fires in the Amazon rainforest? & 4.24 & 0.80 & \\
\hline $\begin{array}{l}\text { How concerned are you about the death of aquatic animals due to waste } \\
\text { in the oceans? }\end{array}$ & 4.29 & 0.75 & \\
\hline How concerned are you about rising global average temperatures? & 4.16 & 0.85 & \\
\hline $\begin{array}{l}\text { How concerned are you about the dramatic decline of polar bears at the } \\
\text { North Pole? }\end{array}$ & 4.05 & 0.62 & \\
\hline How concerned are you about sea level rise? & 4.13 & 0.75 & \\
\hline Environmental Responsibility (ER) & 3.82 & 0.53 & \multirow{6}{*}{0.740} \\
\hline I am aware of environmental impacts before deciding to do something. & 3.73 & 0.58 & \\
\hline I am willing to purchase green products even though I have to pay more. & 3.48 & 0.55 & \\
\hline $\begin{array}{l}\text { I am willing to act environmentally even though I do not feel comfortable, such } \\
\text { as using public transportation, using stairs instead of elevator, etc. }\end{array}$ & 3.69 & 0.50 & \\
\hline It is my responsibility to protect the environment. & 4.10 & 0.50 & \\
\hline $\begin{array}{l}\text { I have tried to use things more efficiently in order to save natural resources, such } \\
\text { as energy saving behaviours, reuse and recycling behaviours, etc. }\end{array}$ & 4.10 & 0.54 & \\
\hline Environmental Attitude (EA) & 3.55 & 0.56 & \multirow{7}{*}{0.700} \\
\hline Ecosystems are vulnerable, and they can be easily deteriorated. & 3.93 & 0.70 & \\
\hline $\begin{array}{l}\text { The nature is strong, and it can cope with consequences of human } \\
\text { development activities. }\end{array}$ & 3.57 & 0.50 & \\
\hline Naturally, existence of plants and animals is for human utilization. & 3.55 & 0.50 & \\
\hline The earth is like a spaceship with finite room and resources. & 4.07 & 0.58 & \\
\hline $\begin{array}{l}\text { If things continue on their present course, we will soon experience a major } \\
\text { ecological catastrophe. }\end{array}$ & 2.84 & 0.55 & \\
\hline Humans have the right to modify the natural environment to suit their needs. & 3.31 & 0.55 & \\
\hline
\end{tabular}

Note: $\mathrm{n}=863$. SD: standard deviation.

\subsection{Path Analysis}

The developed conceptual model (see Figure 1) was tested by performing a path analysis using IBM SPSS Amos 21. First, regarding the model assessment, the results suggested that there was no significant direct effect from environmental attitude (EA) on environmental responsibility (ER); 
therefore, the path from EA to ER was eliminated in order to achieve acceptability of the model. After eliminating the path from EA to ER, the results showed that the overall fit of the model to the data was acceptable (see Figure 2 and Table 5). The value of $\chi^{2}$ was not statistically significant $\left(\chi^{2}=1.991\right.$, $\mathrm{df}$ $=1$, probability level $=0.158$ ). Therefore, there was a close fit between the model and the observed data. All other indexes presented in Table 4 were also statistically accepted. For example, the GFI value must be greater than 0.90 to indicate a close fit between the data and the proposed model. The results of the model assessment showed an acceptable GFI value of 0.999 . The root means square error of approximation (RMSEA) had a value of 0.034 , which is less than 0.08 ; therefore, we can conclude that the model is a reasonable approximation of the data. As suggested by Brown and Cudeck [86], a suitable value of RMSEA that can indicate a reasonable error of approximation, is lower than 0.08 . The results also exhibited a statistically acceptable value for the comparative fit index (CFI). The value of CFI is used to indicate the discrepancy function adjusted for sample size. The result of model evaluation showed a CFI value of 0.999, which indicates a close model fit. Hu and Bentler [87] suggested that an acceptable model fit should have a CFI value of 0.90 or larger. Additionally, the incremental fit index (IFI), used to indicate the possibility of having the worst model, had a value of 0.999 , which is greater than 0.900 , thus indicating the acceptability of the model. Another important index is the CMIN/DF, which indicates how well the data fits the model after dropping one or more paths. The results showed a CMIN/DF value of 1.991, which is considered acceptable [88]. Overall, it can be summarized that the data fits the model, and the proposed model is acceptable after eliminating the path from EA to ER. Since the data fits the model perfectly, this means the use of model for explaining environmental responsibility of general people can be limited.

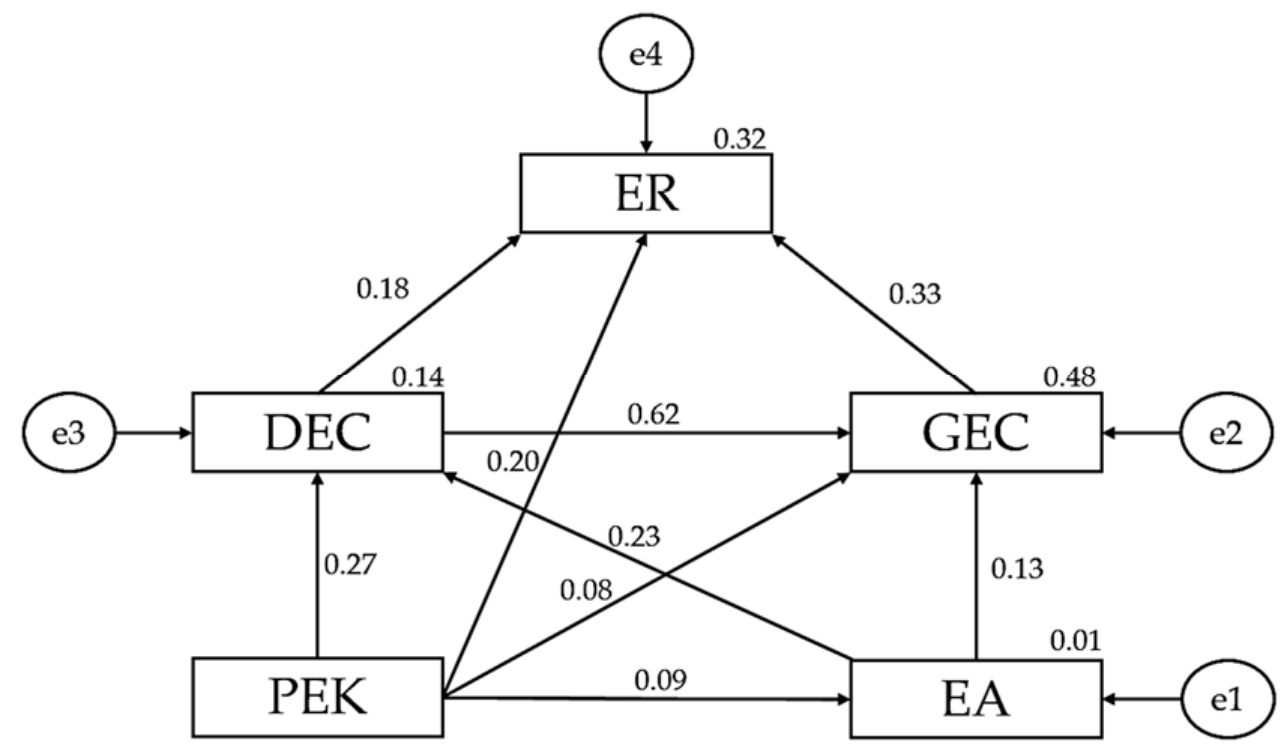

Figure 2. Estimated path analysis model of the effect of perceived environmental knowledge, environmental attitude, and domestic and global environmental on environmental responsibility.

Table 5. Goodness-of-Fit Indices.

\begin{tabular}{ccc}
\hline Indices & Statistics & Accepted Value \\
\hline GFI & 0.999 & $>0.900$ \\
\hline CFI & 0.999 & $\geq 0.900$ \\
\hline RMSEA & 0.034 & $<0.08$ \\
\hline CMIN/DF & 1.991 & $<3$ \\
\hline IFI & 0.999 & $>0.900$ \\
\hline
\end{tabular}


Table 6 presents the effect of all variables on ER (see Table 6). The results demonstrated a squared multiple correlations value of 0.32 . This means approximately $32 \%$ of the variance in ER can be accounted for by the linear combination of investigated variables, including PEK, EA, DEC, and GEC. Additionally, the results of the path analysis revealed that the predicted path from PEK and EA to DEC and GEC, and from DEC and GEC to ER, was statistically significant. Among all variables, the standardized direct effect of GEC on ER was the largest at 0.328 (see Table 7). The standardized direct effect of DEC on ER was 0.181. The predicted path from PEK to EA was also statistically significant, and the standardized direct effect was very small at 0.087 . The predicted path from PEK to DEC was statistically significant, and the standardized direct effect was 0.271 . The predicted path from PEK to GEC was statistically significant, and the standardized direct effect was 0.076. The effect of DEC on GEC was the strongest (0.618), compared to all paths. Additionally, both DEC and GEC mediated the effect of EA on ER, and the effect of PEK on ER. Most importantly, GEC mediated the effect of DEC on ER.

Table 6. Parameter estimates path analysis.

\begin{tabular}{|c|c|c|c|c|c|c|}
\hline & Paths & & Estimate & S.E. & C.R. & $\beta$ \\
\hline Environmental Attitude & $<-$ & $\begin{array}{l}\text { Perceived Environmental } \\
\text { Knowledge }\end{array}$ & 0.086 & 0.034 & 2.572 & $0.087^{*}$ \\
\hline $\begin{array}{l}\text { Domestic Environmental } \\
\text { Concerns }\end{array}$ & $<-$ & $\begin{array}{l}\text { Perceived Environmental } \\
\text { Knowledge }\end{array}$ & 0.332 & 0.039 & 8.554 & $0.271^{* *}$ \\
\hline $\begin{array}{l}\text { Domestic Environmental } \\
\text { Concerns }\end{array}$ & $<-$ & Environmental Attitude & 0.289 & 0.039 & 7.358 & $0.233^{* *}$ \\
\hline $\begin{array}{l}\text { Global Environmental } \\
\text { Concerns }\end{array}$ & $<-$ & Environmental Attitude & 0.179 & 0.034 & 5.196 & $0.133^{* *}$ \\
\hline $\begin{array}{l}\text { Global Environmental } \\
\text { Concerns }\end{array}$ & $<-$ & $\begin{array}{l}\text { Domestic Environmental } \\
\text { Concerns }\end{array}$ & 0.675 & 0.029 & 23.278 & $0.618^{* *}$ \\
\hline $\begin{array}{l}\text { Global Environmental } \\
\text { Concerns }\end{array}$ & $<-$ & $\begin{array}{l}\text { Perceived Environmental } \\
\text { Knowledge }\end{array}$ & 0.101 & 0.034 & 2.934 & $0.076^{*}$ \\
\hline Environmental Responsibility & $<-$ & $\begin{array}{l}\text { Domestic Environmental } \\
\text { Concerns }\end{array}$ & 0.138 & 0.029 & 4.702 & $0.181^{* *}$ \\
\hline Environmental Responsibility & $<-$ & $\begin{array}{l}\text { Global Environmental } \\
\text { Concerns }\end{array}$ & 0.229 & 0.027 & 8.590 & $0.328^{* *}$ \\
\hline Environmental Responsibility & $<-$ & $\begin{array}{l}\text { Perceived Environmental } \\
\text { Knowledge }\end{array}$ & 0.191 & 0.027 & 6.929 & $0.204^{* *}$ \\
\hline
\end{tabular}

Table 7. Direct, indirect and total effects of exogenous variables on endogenous variables.

\begin{tabular}{ccccc}
\hline Exogenous Variables & Endogenous Variable & Direct Effect & Indirect Effect & Total Effect \\
\hline $\begin{array}{c}\text { Perceived Environmental } \\
\text { Knowledge }\end{array}$ & Environmental Responsibility & 0.204 & 0.141 & 0.345 \\
\hline Environmental Attitude & Environmental Responsibility & 0.000 & 0.133 & 0.133 \\
\hline $\begin{array}{c}\text { Domestic Environmental } \\
\text { Concerns }\end{array}$ & Environmental Responsibility & 0.181 & 0.203 & 0.384 \\
\hline Global Environmental Concerns & Environmental Responsibility & 0.328 & 0.000 & 0.328 \\
\hline
\end{tabular}

In total, it can be concluded that GEC had the highest direct effect on ER, followed by PEK and DEC, respectively. EA had no direct effect on ER. PEK was found to be important as it had a strong direct effect on ER, and it also had indirect effects on ER through DEC, GEC and EA (see Table 7). 


\section{Discussion and Conclusions}

This study first found that environmental attitude (EA) was very weak in predicting environmental responsibility (ER). This finding is inconsistent with many previous studies which indicated that ecological worldviews or EA were significant for promoting environmental responsibility [89-91]. For instance, the study of Tengo et al. [91] demonstrated that indigenous peoples' EA could contribute to a sense of responsibility which finally brought environmental sustainability to their areas. People having a belief in the significance of human-nature balance seem to be more responsible to act environmentally. For this study, EA had no direct effect on students' ER. It can be indicated that thought out, students well-perceived the significance of human-nature balance, and this perception would not contribute to students' construction of ER.

According the VBN theory [27], EA had no direct effect on PEBs, but it has a significant effect on PEBs through environmental consciousness and a sense of moral obligation to protect the environment. Therefore, the current study's findings could be supported by the VBN theory; however, it should be indicated that the power of EA in affecting ER was still very weak as it showed an indirect effect on ER of only 0.133. Regarding this total indirect effect value, the greatest value was generated from the indirect effect of EA on ER through the combination of DEC and GEC. This result suggests that students with higher levels of positive environmental attitudes had constructed more environmental concerns. This, in turn, affected their sense of environmental responsibility. Interestingly, DEC also had a very strong direct effect on GEC. Having more concerns about domestic environmental events, students would also construct more global environmental concerns. It is possible that students could relate domestic environmental issues to global environmental issues due to their acquisition of environmental knowledge. Meanwhile, EA helped developing and promoting levels of concern which could be formed based on students' perception of the significance of human-nature balance. The more students perceived values of the nature, the more they were concerned about environmental catastrophic events.

By having sufficient knowledge about environment and nature, students could acquire a basic understanding that all elements of global and domestic environments are connected as a system. Thus, when an environmental problem occurs in one area, it potentially causes environmental problems in other areas. In reality, domestic environmental events potentially create a sense of urgency about being impacted by negative consequences, and this sense contributes to DEC. For global environmental events, people may have a less sense of urgency about being impacted by the events; but global environmental events, in fact, can generate widespread negative impacts, and these impacts can be either directly or indirectly faced by everyone in the world. Based on the findings of this study, it can be pointed out that DEC can be first generated due to students' sense of urgency of being impacted by the negative consequences and perceived severity of impacts. After relating domestic environmental conditions to global environmental conditions, students could consequently construct GEC. Once both GEC and DEC are generated, the combination of DEC and GEC become very powerful to promote ER. Most importantly, the combination of DEC and GEC could significantly mediate the effect of EA on ER, and the effect of perceived environmental knowledge (PEK) on ER.

Considering perceived environmental knowledge (PEK), PEK had both direct and indirect effects on ER. It can be explained that PEK could help individuals understand the qualifications and functions of environmental systems, the potential negative effects of human activities on nature, the severity of adverse consequences and the opportunities available to solve the problems. PEK can enhance people's recognition of their important roles in solving or avoiding environmental problems; thus, PEK could help enhance people's perceived moral responsibility to protect the environment. The study of Pan et al. [81] also found that environmental knowledge positively influenced environmental responsibility of university students from Taiwan. Similarly, the study of Teksoz et al. [92] revealed that environmental knowledge had a significant influence on environmental responsibility of university students. Many studies also found that environmental knowledge significantly affected environmental behaviors through individual sense of responsibility $[81,93,94]$. In addition, PEK had an indirect effect on ER through DEC, GEC and EA. The path analysis showed that the indirect effect of PEK 
on ER through the combination of DEC and GEC was the strongest. The effect of PEK on EA was also important as EA could play an important role in mediating the effect of environmental knowledge on environmental responsibility. Many previous studies also found the link between EA and environmental knowledge $[95,96]$. It could be stated that having more environmental knowledge can support students' formation of environmental attitudes.

However, the novelty of this research is that encouraging people to together acquire concerns about domestic environmental problems and global environmental problems is the most powerful way to create a sense of environmental responsibility to protect the environment. Having both GEC and DEC together could enable people to realize the severity of the problems and how each catastrophic environmental event can potentially cause adverse impacts on both the environment and human well-being. Most importantly, people could recognize the negative consequences of an unsustainable relationship between humans and nature, which can potentially cause problems worldwide. Thus, people with appropriate levels of environmental concerns can be aware of their roles in minimizing these problems.

When considering the role of DEC and GEC in creating students' environmental responsibility, the results demonstrated that GEC had the greater direct effect on ER than DEC. By seeing global environmental problems, such as the death of aquatic animals due to waste in the oceans, and fires in the Amazon rainforest, students might realize the seriousness of global environmental problems. Likewise, they might better understand that these issues can generate vast negative impacts, not only on people in the place where those problems exist, but also on people around the world. Consequently, this realization might influence a student's perception of the urgent need for environmental problem-solving measures. Compared to GEC, the direct influence of DEC on ER was smaller. It is possible that domestic environmental events have a smaller potential impact than global environment events do. However, in promoting students' GEC, DEC could play an important role as the result of this study revealed that DEC had a very strong effect on GEC.

Finally, this study has implications for the development of communication strategies. The results suggest that educating students about both global and domestic environmental events together could effectively help promote students' sense of environmental responsibility. It should be noted that communicating with students only about domestic catastrophic environmental events may have the least direct effect on their sense of environmental responsibility; even though, impacts of domestic environmental events can be easily perceived by students. Once students have domestic environmental concerns, and they are communicated with current global environmental events, their global environmental concerns would be significantly enhanced. Consequently, both domestic and global environmental concerns will have a stronger power to create environmental responsibility among students. However, students should be first provided with basic environmental knowledge which includes issues pertaining to ecosystems, ecological values, environmental phenomena, possible causes of environmental problems and potential impacts. This knowledge would enable students to identify potential adverse effects of global and domestic environmental events or to construct a sense of urgency about being impacted by environmental catastrophic events. Positive environmental attitudes also play an important role in helping students develop environmental responsibility through environmental concerns. Students with positive environmental attitudes will recognize important values of nature, and they would, therefore, have more concerns about environmental problems when being communicated with current environmental events. In sum, it can be concluded that both global and domestic environmental concerns have potential to transfer students' environmental attitudes and environmental knowledge into a sense of responsibility to protect the environment. Therefore, all four elements should be promoted in learning and teaching activities.

\section{Limitations of the Study}

There are some limitations which should be addressed. This study relied on self-reporting for measuring environmental knowledge. This study merely emphasized on the effect of environmental 
concerns, attitudes, and environmental knowledge on students' environmental responsibility; whereas, social relevant factors which may affect sense of responsibility were not included in this study. Further study which can include social factors such as social norms and social relations are recommended.

Author Contributions: P.J. conceived the idea of the study. Both P.J. and S.C. carried out data collection and data analysis. All authors have read and agreed to the published version of the manuscript.

Funding: The research was funded by the School of Liberal Arts, King Mongkut's University of Technology Thonburi, grant number 2563201. The APC was funded by the Research, Innovation, and Partnerships Offices, King Monkut's University of Technology Thonburi, Thailand.

Acknowledgments: The research was financially supported by the School of Liberal Arts, King Mongkut's University of Technology Thonburi. The funding number is 2563201. Furthermore, I would like to thank all students who participated in the questionnaire surveys. Publishing is supported by the Research, Innovation, and Partnerships Offices, King Monkut's University of Technology Thonburi, Thailand.

Conflicts of Interest: The authors declare no conflict of interest.

\section{References}

1. Pollution Control Department (PCD). Thailand State of Pollution Report. 2018. Available online: http: //www.pcd.go.th/file/AW-Pollution-Report2017.pdf (accessed on 10 January 2019).

2. Limsakul, A.; Chidthaisong, A.; Boonprakob, K. Thailand's First Assessment Report on Climate Change 2011 (Working group I: Scientific Basis of Climate Change). THAI-GLOB, Thailand Research Fund. 2011. Available online: http://bit.ly/1TwhLjL (accessed on 23 November 2019). (In Thai).

3. Thailand Meteorological Department. Rainfall and Severe Flooding over Thailand in 2011; Climatological Center, Meteorological Development Bureau: Bangkok, Thailand, 2011. (In Thai)

4. TRF. IPCC ETARC Report: State of Knowledge on the World and Thailand's Climate Change; T-GLOUB, Thailand Research Fund: Bangkok, Thailand, 2011. (In Thai)

5. Limsakul, A.; Singhruck, P. Long-term trends and variability of total and extreme precipitation in Thailand. Atmos. Res. 2016, 169, 301-317. [CrossRef]

6. AHA Center. Tropical Storm Podul and Tropical Depression Kajiki Thailand, Flash Update\#2. 2019. Available online: https://reliefweb.int/sites/reliefweb.int/files/resources/FlashUpdate_02_22Sep_TH_TS-PODUL-TDKAJIKI_revGE.pdf (accessed on 23 November 2019).

7. Antonelli, A.; Zizka, A.; Carvalho, F.A.; Scharn, R.; Bacon, C.D.; Silvestro, D.; Condamine, F.I. Amazonia is the primary source of Neotropical biodiversity. Proc. Natl. Acad. Sci. USA 2018, 115, 6034-6039. [CrossRef] [PubMed]

8. World Wide Fund. WWF Living Amazon Report. 2016. Available online: https://c402277.ssl.cf1.rackcdn.com/ publications/889/files/original/LIVING_AMAZON_REPORT_2016_MID_RES_SPREADS.pdf?1465588596 (accessed on 20 November 2019).

9. National Institute for Space Research. 2019. Available online: http:/queimadas.dgi.inpe.br/queimadas/ portal-static/situacao-atual/ (accessed on 20 November 2019).

10. Marine Debris. Marine Debris: Understanding, Preventing and Mitigating the Significant Adverse Impacts on Marine and Coastal Biodiversity; Technical Series No.83; Secretariat of the Convention on Biological Diversity: Montreal, QC, Canada, 2016; 78p.

11. Anbumani, S.; Kakkar, P. Ecotoxicological effects of microplastics on biota: A review. Environ. Sci. Pollut. Res. Int. 2018, 25, 14373-14396. [CrossRef] [PubMed]

12. NOAA National Centers for Environmental Information. State of the Climate: Global Climate Report for Annual 2017. January 2018. Available online: https://www.ncdc.noaa.gov/sotc/global/201713 (accessed on 2 August 2019).

13. Amstrup, S.C. Polar bear, Ursus Maritimus. In Wild Mammals of North America; Feldhamer, G.A., Thompson, B.C., Chapman, J.A., Eds.; John Hopkins University Press: Baltimore, MD, USA, 2003; pp. 587-610.

14. Bergen, S.; Durner, G.M.; Douglas, D.C.; Amstrup, S.C. Predicting Movements of Female Polar Bears between Summer Sea Ice Foraging Habitats and the Terrestrial Denning Habitats of Alaska in the 21st Century: Proposed Methodology and Pilot Assessment; US Geological Survey Administrative Report: Reston, VA, USA, 2007. 
15. Hunter, C.M.; Caswell, H.; Runge, M.C.; Regehr, E.V.; Amstrup, S.C.; Stirling, I. Polar Bears in the Southern Beaufort Sea II: Demography and Population Growth in Relation to Sea Ice Conditions; Administrative Report; USGS Alaska Science Center: Anchorage, AK, USA, 2007.

16. Bromaghin, J.F.; Mcdonald, T.L.; Stirling, I.; Derocher, A.E.; Richardson, E.S.; Regehr, E.V.; Douglas, D.C.; Durner, G.M.; Atwood, T.; Amstrup, S.C. Polar bear population dynamics in the southern Beaufort Sea during a period of sea ice decline. Ecol. Appl. 2015, 25, 634-651. [CrossRef]

17. Church, J.A.; Clark, P.U.; Cazenave, A.; Gregory, J.M.; Jevrejeva, S.; Levermann, A.; Merrifield, M.A.; Milne, G.A.; Nerem, R.S.; Nunn, P.D.; et al. Sea Level Change. In Climate Change 2013. The Physical Science Basis; Contribution of Working Group I to the Fifth Assessment Report of the Intergovernmental Panel on Climate; Cambridge University Press: Cambridge, UK; New York, NY, USA, 2013.

18. Church, J.A.; White, N.J. A 20th century acceleration in global sea-level rise. Geophys. Res. Lett. 2006, 33, L01602. [CrossRef]

19. Intergovernmental Panel on Climate Change. Summary for Policymakers. 2013. Available online: http://www.ipcc.ch/report/ar5/wg1/ (accessed on 26 August 2019).

20. Liobikienè, G.; Poškus, M.S. The Importance of Environmental Knowledge for Private and Public Sphere Pro-Environmental Behavior: Modifying the Value-Belief-Norm Theory. Sustainability 2019, 11, 3324. [CrossRef]

21. Slavoljub, J.; Zivkovic, J.; Sladjana, A.; Dragica, G.; Zorica, P.J. To the environmental responsibility among students through developing their environmental values. Procedia Soc. Behav. Sci. 2015, 171, 317-322. [CrossRef]

22. Arisal, I.; Atalar, T. The exploring relationship between environmental concern, collectivism and ecological purchase intention. Procedia Soc. Behav. Sci. 2016, 25, 514-521. [CrossRef]

23. Chen, M.-F.; Tung, P.-J. Developing an extended Theory of Planned Behavior model to predict consumers' intention to visit green hotels. Int. J. Hosp. Manag. 2014, 36, 221-230. [CrossRef]

24. Li, G.; Li, W.; Jin, Z.; Wang, Z. Influence of Environmental Concern and Knowledge on Households' Willingness to Purchase Energy-Efficient Appliances: A Case Study in Shanxi, China. Sustainability 2019, 11, 1073. [CrossRef]

25. Clark, C.F.; Kotchen, M.J.; Moore, M.R. Internal and external influences on pro-environmental behavior: Participation in a green electricity program. J. Environ. Psychol. 2003, 23, 237-246. [CrossRef]

26. Han, H.; Hwang, J.; Lee, S. Cognitive, affective, normative, and moral triggers of sustainable intentions among convention-goers. J. Environ. Psychol. 2017, 51, 1-13. [CrossRef]

27. Stern, P. Toward a coherent theory of environmentally significant behavior. J. Soc. Issues 2000, 56, 407-424. [CrossRef]

28. Liobikienè, G.; Juknys, R. The role of values, environmental risk perception, awareness of consequences, and willingness to assume responsibility for environmentally-friendly behaviour: The Lithuanian case. J. Clean. Prod. 2016, 112, 3413-3422. [CrossRef]

29. Zareie, B.; Navimipour, N.J. The impact of electronic environmental knowledge on the environmental behaviors of people. Comput. Hum. Behav. 2016, 59, 1-8. [CrossRef]

30. Wang, Z.H.; Zhang, B.; Li, G. Determinants of energy-saving behavioral intention among residents in Beijing: Extending the theory of planned behavior. J. Renew. Sustain. Energy 2014, 6, 17. [CrossRef]

31. Zhu, H.; Wong, N.; Huang, M. Does relationship matter? How social distance influences perceptions of responsibility on anthropomorphized environmental objects and conservation intentions. J. Bus. Res. 2019, 95, 62-70. [CrossRef]

32. Barr, S. Strategies for Sustainability: Citizens and Responsible Environmental Behavior. Area 2003, 35, 227-240. [CrossRef]

33. Kaiser, F.G.; Shimoda, T.A. Responsibility as a predictor of ecological behaviors. J. Environ. Psychol. 1999, 19, 1-19. [CrossRef]

34. Abrahamse, W.; Steg, L. How do socio-demographic and psychological factors relate to households' direct and indirect energy use and savings? J. Econ. Psychol. 2009, 30, 711-720. [CrossRef]

35. Schultz, P.W.; Shriver, C.; Tabanico, J.; Khazian, A. Implicit connections with nature. J. Environ. Psychol. 2004, 24, 31-42. [CrossRef] 
36. Masud, M.M.; Aldakhil, A.M.; Nassani, A.A.; Azam, M.N. Community-based ecotourism management for sustainable development of marine protected areas in Malaysia. Ocean Coast. Manag. 2017, 136, 104-112. [CrossRef]

37. Lee, J.-H.; Choi, H.O. Stakeholders' views on reducing financial support in government-led ecotourism areas. Ocean Coast. Manag. 2017, 144, 7-15. [CrossRef]

38. Kim, K.J. Visitor Interpretation and Sustainable Tourism: A Study of the Role of Interpretation in Influencing Attitudes and Behaviour toward Environmental Conservation. Ph.D. Thesis, School of Management, University of Surrey, Guildford, UK, 2007.

39. Dunlap, R.E.; Van Liere, K.D. The new environmental paradigm: A proposed measuring instrument and preliminary results. J. Environ. Educ. 1978, 9, 10-19. [CrossRef]

40. Mohai, P. Men, women, and the environment: An examination of the gender gap in environmental concern and activism. Soc. Natl. Resour. 1992, 62, 475-505. [CrossRef]

41. Weaver, R.D. Prosocial behavior: Private contributions to agriculture's impact on the environment. Land Econ. 1996, 72, 231-247. [CrossRef]

42. Olli, E.; Grendstad, G.; Wollebaek, D. Correlates of environmental behaviours: Bringing back social context. Environ. Behav. 2001, 33, 181-208.

43. Paço, A.; Lavrador, T. Environmental knowledge and attitudes and behaviours towards energy consumption. J. Environ. Manag. 2017, 197, 384-392. [CrossRef]

44. Vermeir, I.; Verbeke, W. Sustainable food consumption: Exploring the consumer "attitudeebehavioral intention" gap. J. Agric. Environ. Ethics 2006, 19, 169-194. [CrossRef]

45. Schultz, P.; Zelezny, L. Values as predictors of environmental attitudes: Evidence for consistency across 14 countries. J. Environ. Psychol. 1999, 19, 255-265. [CrossRef]

46. Johnson, C.; Bowker, J.M.; Cordell, H. Ethnic variation in environmental belief and behavior: An examination of the New Ecological Paradigm in a social psychological context. Environ. Behav. 2004, 32, 157-186. [CrossRef]

47. Arcury, T. Environmental Attitude and Environmental Knowledge. Hum. Organ. 1990, 49, 300-304. [CrossRef]

48. Dunlap, R.E.; Van Liere, K.D.; Mertig, A.; Jones, R.E. Measuring endorsement of the new ecological paradigm: A revised NEP scale. J. Soc. Issues 2000, 56, 425-442. [CrossRef]

49. Fransson, N.; Gärling, T. Environmental concern: Conceptual definitions, measurement methods, and research findings. J. Environ. Psychol. 1999, 19, 36-382. [CrossRef]

50. Halkos, G.; Matsiori, S. Environmental attitude, motivations and values for marine biodiversity protection. J. Behav. Exp. Econ. 2017, 69, 61-70. [CrossRef]

51. Laroche, M.; Bergeron, J.; Barbaro-Forleo, G. Targeting consumers who are willing to pay more for environmentally friendly products. J. Consum. Mark. 2001, 18, 503-520. [CrossRef]

52. Chan, R.Y.; Lau, L.B. Antecedents of green purchases: A survey in China. J. Consum. Mark. 2000, 17, 338-357. [CrossRef]

53. Ünal, A.B.; Steg, L.; Gorsira, M. Values Versus Environmental Knowledge as Triggers of a Process of Activation of Personal Norms for Eco-Driving. Environ. Behav. 2018, 50, 1092-1118. [CrossRef]

54. Lee, K. The green purchase behavior oh Hong Kong young consumers: The role of peer influence local environmental involvement, and concrete environmental knowledge. J. Int. Consum. Mark. 2010, 23, 21-44. [CrossRef]

55. Mostafa, M.M. A hierarchical analysis of the green consciousness of the Egyptian consumers. Psychol. Mark. 2017, 24, 445-473. [CrossRef]

56. Oguz, D.; Çakci, I.; Kavas, S. Environmental awareness of university students in Ankara, Turkey. Afr. J. Agric. Res. 2005, 5, 2629-2636.

57. Flamm, B. The impacts of environmental knowledge and attitudes on vehicle ownership and use. Transp. Res. Part D Transp. Environ. 2009, 14, 272-279. [CrossRef]

58. Otto, S.; Kaiser, F.G. Ecological behavior across the lifespan: Why environmentalism increases as people grow older. J. Environ. Psychol. 2014, 40, 331-338. [CrossRef]

59. Abrahamse, W.; Steg, L.; Vlek, C.; Rothengatter, T. A review of intervention studies aimed at household energy conservation. J. Environ. Psychol. 2005, 25, 273-291. [CrossRef] 
60. Mostafa, M.M. Shades of green: A psychographic segmentation of the green consumer in Kuwait using self-organizing maps. Expert Syst. Appl. 2009, 36, 11030-11038. [CrossRef]

61. Sang, Y.N.; Bekhet, H.A. Modelling electric vehicle usage intentions: An empirical study in Malaysia. J. Clean. Prod. 2015, 92, 75-83. [CrossRef]

62. Dodd, T.H.; Laverie, D.A.; Wilcox, J.F.; Duhan, D.F. Differential effects of experience, subjective knowledge, and objective knowledge on sources of information used in consumer wine purchasing. J. Hosp. Tour. Res. 2005, 29, 3-19. [CrossRef]

63. Hartmann, P.; Apaolaza-Ibánez, V. Consumer attitude and purchase intention toward green energy brands: The roles of psychological benefits and environmental concern. J. Bus. Res. 2012, 65, 1254-1263. [CrossRef]

64. Dunlap, R.E.; Jones, R.E. Environmental concern conceptual and measurement issues. In Handbook of Environmental Sociology; Dunlap, R.E., Michwlson, W., Eds.; Greenwood Publishing Group: Westport, CT, USA, 2000; pp. 44-524.

65. Singh, A.; Bansal, M. Green marketing: A study of consumer attitude and environment concern. Indian J. Commer. 2012, 65, 273-283.

66. Russell, W.; Joan, W. Environmental concern: The development of a measure. Environ. Behav. 1978, 10, 3-15.

67. Abdul-Muhmin, A.G. 'Explaining consumers' willingness to be environmentally friendly. Int. J. Consum. Stud. 2007, 31, 237-247. [CrossRef]

68. Wu, J.; Liao, H.; Wang, J.W.; Chen, T. The role of environmental concern in the public acceptance of autonomous electric vehicles: A survey from China. Transp. Res. Part F Traffic Psychol. Behav. 2019, 60, 37-46. [CrossRef]

69. Evans, G.W. Projected behavioral impacts of global climate change. Annu. Rev. Psychol. 2019, 70, 449-474. [CrossRef] [PubMed]

70. Widegren, O. The new environmental paradigm and personal norms. Environ. Behav. 1998, 30, 75-100. [CrossRef]

71. Maharjan, K.L.; Joshi, N.P. Climate Change, Agriculture and Rural Livelihoods in Developing Countries with reference to Nepal; Hiroshima International Center for Environment Cooperation (HICEC), IDEC, Hiroshima University: Hiroshima, Japan, 2012.

72. Nash, N.; Capstick, S.; Whitmarsh, L.; Chaudhary, I.; Manandhar, R. Perceptions of Local Environmental Issues and the Relevance of Climate Change in Nepal's Terai: Perspectives from Two Communities. Front. Sociol. 2019, 4, 60. [CrossRef]

73. Bradley, J.C.; Waliczek, T.M.; Zajicek, J.M. Relationship between Environmental Knowledge and Environmental Attitude of High School Students. J. Environ. Educ. 1999, 30, 17-21. [CrossRef]

74. Wurzinger, S.; Johansson, M. Environmental concern and knowledge of ecotourism among three groups of swedish tourists. J. Travel Res. 2006, 45, 217-226. [CrossRef]

75. Hunter, L.M.; Rinner, L. The association between environmental perspective and knowledge and concern with species diversity. Soc. Natl. Resour. 2004, 17, 517-532. [CrossRef]

76. Lin, P.C.; Huang, Y.K. The influence factors on choice behavior regarding green products based on the theory of consumption values. J. Product Prod. 2012, 22, 11-18. [CrossRef]

77. Prakash, G.; Pathak, P. Intention to buy eco-friendly packaged products among young consumers of India: A study on developing nation. J. Clean. Prod. 2017, 141, 385-393. [CrossRef]

78. Yamane, T. Statistics: An Introductory Analysis, 3rd ed.; Harper \& Row: New York, NY, USA, 1973.

79. Nunnally, J.C. Psychometric Theory, 2nd ed.; McGraw-Hill: New York, NY, USA, 1978.

80. Zhu, Y. An Assessment of Environmental Literacy among Undergraduate Students at Two National Universities in Hubei Province, China; Florida Institute of Technology: Melbourne, FL, USA, 2015.

81. Pan, S.L.; Chou, J.; Morrison, A.M.; Huang, W.S.; Lin, M.C. Will the Future Be Greener? The Environmental Behavioral Intentions of University Tourism Students. Sustainability 2018, 10, 634. [CrossRef]

82. Corral-Verdugo, V. Dual 'realities' of conservation behavior: Self-reports vs. observations of re-use and recycling behavior. J. Environ. Psychol. 1997, 17, 135-145. [CrossRef]

83. Hawcroft, L.J.; Milfont, T.L. The use (and abuse) of the new environmental paradigm scale over the last 30 years: A meta-analysis. J. Environ. Psychol. 2010, 30, 143-158. [CrossRef]

84. Dunlap, R.E.; Gallup, G.; Gallup, A. Global environmental concern: Results from an international public opinion survey. Environment 1993, 35, 7-15. 
85. Jagers, S.C.; Matti, S. Ecological Citizens: Identifying Values and Beliefs that Support Individual Environmental Responsibility among Swedes. Sustainability 2010, 2, 1055-1079. [CrossRef]

86. Brown, M.W.; Cudeck, R. Alternative Ways of Assessing Model Fit. In Testing Structural Equation Models; Bollen, K.A., Long, J.S., Eds.; Sage: Newbury Park, CA, USA, 1993; pp. 136-162.

87. Hu, L.; Bentler, P.M. Cutoff criteria for fit indexes in covariance structure analysis: Conventional criteria versus new alternatives. Struct. Equ. Model. Multidiscip. J. 1999, 6, 1-55. [CrossRef]

88. Kline, R.B. Principles and Practice of Structural Equation Modeling; Guilford Press: New York, NY, USA, 1998.

89. Lwo, L.S.; Fu, J.H.; Chang, C.C. The Ecological Worldviews and Local Environmental Concerns among Secondary School Teachers. J. Balt. Sci. Educ. 2017, 16, 706-722.

90. Timoti, P.; O’BLyver, P.; Matamua, R.; Jones, C.J.; Tahi, B.L. A representation of a Tuawhenua worldview guides environmental conservation. Ecol. Soc. 2017, 22, 20. [CrossRef]

91. Tengo, M.; Hill, R.; Malmer, P.; Raymond, C.M.; Spierenburg, M.; Danielsen, F.; Elmqvist, T.; Folke, C. Weaving knowledge systems in IPBES, CBD and beyond-Lessons learned for sustainability. Curr. Opin. Environ. Sustain. 2017, 26-27, 17-25. [CrossRef]

92. Teksoz, G.; Sahin, E.; Tekkaya-Oztekin, C. Modeling Environmental Literacy of University Students. J. Sci. Educ. Technol. 2011, 21, 157-166. [CrossRef]

93. Rahman, N.A. Knowledge, internal, and environmental factors on environmental care behaviour among aboriginal students in Malaysia. Int. J. Environ. Sci. Educ. 2016, 11, 5349-5366.

94. Jansson, J.; Marell, A.; Nordlund, A. Green consumer behavior: Determinants of curtailment and eco-innovation adoption. J. Consum. Mark. 2010, 27, 358-370. [CrossRef]

95. Boeve-de Pauw, J.; van Petegem, P. The effect of Flemish eco-schools on student environmental knowledge, attitudes, and affect. Int. J. Sci. Educ. 2011, 33, 1513-1538. [CrossRef]

96. Bogner, F.X. The influence of short-term outdoor ecology education on long-term variables of environmental perspective. J. Environ. Educ. 1998, 29, 17-29. [CrossRef]

(C) 2020 by the authors. Licensee MDPI, Basel, Switzerland. This article is an open access article distributed under the terms and conditions of the Creative Commons Attribution (CC BY) license (http://creativecommons.org/licenses/by/4.0/). 